\title{
Lung maturation
}

\author{
BY ROBERT HUME, CHRISTINE CONNER AND \\ MHAIRI GILMOUR \\ Departments of Child Health, Obstetrics and Gynaecology and Biochemical Medicine, \\ University of Dundee Medical School, Ninewells Hospital, Dundee DD1 9SY
}

\section{La maturation des poumons}

\section{RÉSUMÉ}

Le développement structurel et fonctionnel adéquat du poumon chez le foetus in utero est essentiel pour permettre une adaptation rapide et satisfaisante aux échanges gazeux extra-utérins, et si cette fonction est retardée ou anormale, il y a bien des chances qu'apparaisse une insuffisance respiratoire néonatale.

Le développement des poumons dépend de l'interaction entre un bourgeon de l'endoderme à partir de l'intestin primitif et le mésoderme splanchique qu'il envahit. On divise habituellement le développement des poumons chez le foetus en deux étapes, par exemple, chez les humains il y a une phase de sac embryonnaire (de 3-7 semaines), pseudoglandulaire (de 7-16 semaines), canaliculaire (de 16-24 semaines), et terminale (de 24 semaines au terme). La régulation du développement de l'ontogénie des poumons est une interaction complexe de multiples niveaux d'interaction du contrôle moléculaire. Chez la Drosophile, des gènes contenant des domaines d'homéobox agissent comme des facteurs de transcription et peuvent activer de multiples gènes pendant le développement, et des gènes homologues chez les animaux d'espèces supérieures, les gènes $H o x$, ont été impliqués dans l'affectation de l'identité cellulaire dans les poumons au stade embryonnaire précoce. Tous les membres de la famille des $m y c$ des oncogènes cellulaires sont exprimés à des niveaux élevés dans les poumons embryonnaires, mais seuls le myc-L et le $m y c-\mathrm{N}$ ont une spécificité temporelle et spatiale et peuvent jouer des rôles dans la régulation de la mitose et de la différenciation des poumons. Les interactions entre les cellules de l'épithélium et celles du mésenchyme sont importantes dans la détermination de l'organisation spatiale et temporelle des poumons en développement, en particulier la morphogenèse cies branchements dans la phase pseudoglandulaire, et ces effects peuvent se faire sous la médiation d'interactions directes de cellule à cellule, ou de mécanismes intermédiaires tels que les interactions avec les composants extracellulaires de l'utérus, ou de cytokines et les facteurs de croissance. Les événements de la maturation à la fin de la phase de sac canaliculaire ou au début de la phase terminale entre 20 et 30 semaines de gestation, y compris la dilatation des bronchioles, l'approche des capillaires et de l'épithélium et la formation des pneumocytes de type I (échanges gazeux) et de type II (production de surfactant) sont des déterminants de la survie liée à l'âge de la gestation. Le surfactant est un complexe lipoprotéinique produit par des pneumocytes de type II qui réduit la tension de surface des voies aériennes, et a une composition unique avec une teneur élevée en dipalmitoylphosphatidylcholine et de phosphatidylglycérol et en protéines spécifiques SP-A, SP-B et SP-D. Les composants individuels sont régulés 
indépendamment par des hormones et des facteurs de croissance comme les glucocorticoïdes, la thyroxine, l'EGF et le TGFb. Les facteurs qui augmentent les niveaux d'AMP cyclique dans les cellules des poumons du foetus comme le PGE2, accélèrent la maturation morphologique des poumons et augmentent la synthèse du surfactant qui comprend la SP-AmARN et la protéine.

La sécrétion de fluide des poumons du foetus implique un mécanisme basé sur une sécrétion d'ions de chlorure, secondairement active, et la distension de fluide dans les voies aériennes in utero joue un rôle dans le contrôle de la croissance des poumons du foetus, avec une compression des poumons et une réduction de l'espace pour l'expansion du volume des poumons, aboutissant à une hypoplasie des poumons. A l'inverse, les augmentations de l'expansion du volume des poumons résultent et une hyperplasie des poumons. La croissance des poumons est particulièrement sensible à la sousalimentation de la mère, au stress du froid chronique de la mère et aux restrictions alimentaires du foetus. La base moléculaire de ces processus physiopathologiques qui compromettent la croissance des poumons du foetus reste en grande partie inexplorée. Il semble que la détermination à venir de la contribution de l'alimentation à la maturation des poumons devrait avoir une importance fondamentale, non seulement pour le bien-être du foetus et du nouveau-né, mais au-delà jusque dans l'âge adulte.

Adequate structural and functional development of the fetal lung in utero is essential to allow rapid and successful adaptation of the newborn to extrauterine gas exchange and if this is delayed or abnormal, then neonatal respiratory insufficiency is likely. Respiratory distress syndrome is the consequence of failure of fetal lung maturation and in the UK 6000 preterm infants per year suffer the severest form of the disease. The nature of regulation of development of this phase of lung maturation has been studied extensively because of the obvious clinical importance.

However, there is increasing evidence that events in fetal life may have effects which extend into adulthood (Barker, 1992) and recent studies have highlighted the sensitivity of lung development to adverse circumstances in utero. Lung growth is particularly sensitive to maternal nutrition and is significantly compromised after $10-20 \mathrm{~d}$ of undernutrition during mid to late gestation in sheep (Harding, 1996). Similarly lung growth is reduced following chronic maternal undernutrition over the last 6 weeks of gestation in sheep, although this effect can be overcome by maternal cold exposure which also increases lamb birth weight (Symonds et al. 1996). In animal models of fetal malnutrition, lung growth is compromised (Rees et al. 1991) and in intrauterine-growthretarded human infants, the number of terminal ducts per bronchiole is reduced (Beech et al. 1995). The molecular basis of these pathophysiological processes which compromise fetal lung growth remains largely unexplored and the aim of the present article is to review the developmental regulation of lung maturation.

\section{MORPHOLOGY OF FETAL LUNG DEVELOPMENT}

Human lung development is dependent on the interaction between an endodermal bud from the developing foregut and the splanchnic mesoderm which it invades. The developmental stages are usually divided into embryonic (3-7 weeks), pseudoglandular (7-16 weeks), canilicular (16-24 weeks) and a terminal sac phase (24 weeks to term) (Hislop \& Reid, 1974). 


\section{Embryonic phase}

During the embryonic phase, the endodermal outgrowth from the primitive oesophagus subdivides at about 4 weeks into two sacs forming the primitive lung buds. The lung buds develop lobar buds corresponding to the mature lung and by about 6-7 weeks the lobar buds have further subdivided to form the bronchopulmonary segments (O'Rahilly, 1988).

\section{Pseudoglandular phase}

During this phase of development, from 7-16 weeks gestation, the bronchial tree undergoes repeated dichotomous branching resulting in sixteen to twenty-five generations of presumptive airways. By the end of this phase all the bronchial airways have been formed with the bronchiolar tree ending in terminal bronchii from which three or four orders of respiratory bronchii originate. In turn, the respiratory bronchii end in terminal sacs which are the presumptive alveolar ducts (Hislop \& Reid, 1974).

\section{Canilicular phase}

During the late canilicular phase, from 20 to 24 weeks gestation, specialization of the respiratory portion of the lung begins with dilatation of the terminal airways and differentiation of the progenitor epithelium to type I (gas exchanging) and type II (surfactant producing) pneumatocytes. The progenitor epithelium is partially differentiated, expressing only some of the proteins of the fully-differentiated cell (Cossar et al. 1993). The progression of a progenitor cell to a type II pneumatocyte is likely to involve several intermediate cell stages. Many studies have shown that type I and type II pneumatocytes are developmentally related and that type I cells are derived from type II (for example Hansbrough et al. 1993).

\section{Terminal-sac phase}

The development of the respiratory airway continues through the terminal-sac phase, initially with the formation of dilated saccules separated by primary septae. The next stages in the process of lung maturation are critically dependent on mesenchymal events, i.e. vascularization and elastin deposition. Elastin, as a supporting fibrous network, is present around major airways and lung blood vessels as early as 9-12 weeks gestation and extends distally along the conducting airways to the necks of the dilating saccules. Elastin development around terminal airways is delayed until 23-24 weeks gestation and the formation of foci of elastin deposition at key points around the dilating saccule is a critical initial event in the subdivision of the saccule and the eventual formation of alveolar spaces. At about 26-27 weeks gestation and at those foci of elastin deposition around the dilating saccule, secondary septae containing a capillary loop begin to arise from the primary septae and grow into the lumen of the saccule. Further elongation and thinning of these secondary septae along with the development of a single capillary network morphologically marks the acquisition of an alveolar structure, which can be seen as early as 29 weeks gestation, and is usually present in all lungs by 36 weeks gestation. At term, alveolar numbers vary widely but human lung has on average 
$150 \times 10^{6}$ alveoli, around half the adult complement. Alveolar numbers continue to increase through childhood until about 8 years of age (Hislop et al. 1986).

\section{PULMONARY SURFACTANT}

Pulmonary surfactant is a lipoprotein complex in which glycerophospholipids and several specific proteins interact to reduce surface tension at the air-liquid interface. Surfactant is synthesized by type II pneumatocytes which can be identified as early as 22 weeks gestation, although amounts of surfactant in amniotic fluid rise significantly only after 30 weeks gestation.

\section{Surfactant phospholipids}

Pulmonary surfactant has a unique composition because it contains a high proportion of dipalmitoylphosphatidylcholine (DPPC), $>50 \%$ of total surfactant glycerophospholipids, and in addition contains large amounts, up to $10 \%$, of phosphatidylglycerol (PG). The surfactant initially synthesized by fetal lung is rich in DPPC but contains only small amounts of PG, although relatively large amounts of an acidic glycerophospholipid, phosphatidylinositol (PI), are present. As gestation proceeds the PG:PI ratio changes; in the human fetus, from 0.04 at 35 weeks gestation to 1.75 at term. The role of PG in surfactant function has not been clearly defined, although the wide variability of content in mammalian surfactant and substitution studies in animals suggests its role is not critical for surfactant function. The relative proportions of PG:PI synthesized by fetal lung may be under multi-hormonal control and glucocorticoids acting in concert with prolactin or insulin stimulate DPPC formation but also alter the relative rates of synthesis of PG and PI, resulting in surfactant rich in PG with reduced PI (Snyder et al. 1983).

\section{Surfactant proteins}

Four surfactant-associated proteins, SP-A, SP-B, SP-C and SP-D, have been characterized. Their potential importance in the reduction of alveolar surface tension and in endocytosis and re-utilization of secreted surfactant by type II cells has stimulated research into the structures of the surfactant proteins and their genes. The genes encoding SP-A, SP-B and SP-C are expressed in a cell-specific manner and are independently developmentally regulated (Gross, 1990; Mendelson \& Boggaram, 1991).

\section{Surfactant protein $S P-A$}

The major surfactant-associated protein, SP-A, has multiple functions including a role in reduction of alveolar tension, but also acts as a mediator of endocytosis and re-utilization of secreted surfactant by binding to high-affinity receptors on type II cells. This may in turn act in a negative feedback manner to regulate surfactant synthesis and secretion. In addition, SP-A may, in concert with $\mathrm{Ca}$ and the hydrophobic surfactant proteins SP-B and SP-C, assist in the conversion of the physical state of surfactant from the secreted lamellar body to that of tubular myelin (for example Ryan et al. 1989). The expression of the SP-A gene is developmentally regulated and, in general, reflects the appearance and increasing function of type II pneumatocytes. SP-A protein is modified post- 
translationally by glycosylation, and as this increases with gestational age it is reflected in an apparent increase in molecular weight of SP-A; the functional consequences of this are not clear (Torday et al. 1981; Snyder et al. 1988). SP-A gene expression is exclusively localized to lung; immunohistochemical methods localize the protein to type II cells, non-ciliated bronchiolar cells and alveolar macrophages, whereas in situ hybridization techniques to detect SP-A mRNA suggest that the main site of mRNA production in late gestation is only the type II pneumatocyte. The appearance of SP-A protein, but not mRNA, in cell types other than type II pneumatocytes is likely to reflect secondary uptake of secreted surfactant, although a synthetic role for bronchial cells in earlier gestation has not been excluded (for example Endo \& Oka, 1991).

\section{Surfactant proteins $S P-B, S P-C$ and $S P-D$}

The two smaller hydrophobic proteins SP-B (7-8 kDa) and SP-C (4-5 kDa) have important functions in reducing surface tension and promoting the conversion of lamellar to tubular myelin. The expression of genes encoding SP-B and SP-C occurs at an earlier stage of development than SP-A, as early as 13 weeks, and thereafter increases with gestation. SP-B mRNA has been detected in type II pneumatocytes and bronchiolar cells (Pilot-Matias et al. 1989). The distribution of gene expression may change with development, as SP-C mRNA is found in all epithelial cells before the appearance of type II pneumatocytes, but the function of this protein in early fetal lung is unknown (for example Wohlford-Lenane et al. 1992). SP-D is synthesized by type II pneumatocytes and non-ciliated bronchiolar cells and in rats, lung and amniotic levels increase before birth.

\section{DEVELOPMENTAL GENE EXPRESSION}

Foregut endoderm provides the common embryological precursor for the diversity of cell types which are spatially organized throughout the epithelium of the tracheobronchial tree. How this controlled developmental organization of cell types is achieved is poorly understood. However, it is likely that both in endoderm and mesoderm major changes occur in the expression of a few key developmental genes, which in turn influence the expression of many other genes whose ultimate protein products determine the specialized cell phenotype.

\section{Hox genes}

In Drosophila, homeotic genes whose protein products contain a highly conserved sixty amino acid domain known as the homeobox are thought to be involved in the assignment of cellular identity. Genes containing homeobox domains act as transcription factors and can activate multiple genes during development. The mammalian equivalents of the Drosophila homeotic genes are thought to play a similar role in the development of lung, and homologous genes in higher animals are arranged in four gene clusters or Hox loci (Graham et al. 1989). In lung, specific genes from the four gene clusters are expressed in the mesenchyme of the embryonic lung in a highly conserved sequence as the bronchopulmonary tree develops (Gaunt et al. 1989). For example, Hox 1.4 and 2.6 mRNA levels increase with gestation in murine embryo lung at a time of maximal 
branching morphogenesis; however, when Hox 1.4 gene is overexpressed in transgenic mice, no morphological abnormalities are observed (Wolgemuth et al. 1989). Further investigation is required to delineate the role of $H o x$ gene products in early lung development.

$N$-myc genes

All members of the myc family of cellular oncogenes are expressed in high levels in the embryo but only L-myc and N-myc have temporal and spatial specificity. The pattern of expression in the embryo suggests that $\mathrm{N}-m y c$ expression may correlate more clearly with differentiation than with the control of mitosis, as N-myc mRNA decreases with gestation and is confined to proximal airways in late embryos (for example Hirning et al. 1991). In homozygous transgenic mice with mutations in the $\mathrm{N}-m y c$ locus, abnormalities are confined to developing airways with defects in branching morphogenesis (Moens et al. 1992). A similar but more severe pattern of abnormality is seen in transgenic mice with null mutations at the $\mathrm{N}$-myc locus (Sawai et al. 1993).

\section{wnt genes}

The wnt family of genes encodes at least eleven proteins which have been implicated in intercellular communications during development and may be involved in pattern formation (Gavin et al. 1990). Many of the wnt gene products are expressed in lung and $w n t-2$ mRNA has been detected in fetal lung fibroblasts. The expression of $w n t-2$ gene is down-regulated by basic fibroblast growth factor (FGF) and epidermal growth factor (EGF) (Levay-Young \& Navre, 1992).

\section{EPITHELIAL-MESENCHYMAL INTERACTIONS IN LUNG MATURATION}

Interactions between epithelial and mesenchymal cells are important in determining spatial and temporal organization in developing organs and these effects may be mediated through direct cell-cell interactions or through intermediate mechanisms such as interactions with the extracellular matrix components or through cytokines and growth factors.

\section{Extracellular matrix components}

Laminin is a glycoprotein localized primarily in the basement membrane and is present through all stages of development (Wu et al. 1983). Anti-laminin antibodies inhibit branching morphogenesis, with specificity localized to specific domains within the laminin molecule (Schuger et al. 1991). Fibronectin functions as a cell adhesive glycoprotein during development but is also increased in response to lung injury (for example Vartio et al. 1987) and may also have chemotactic functions. Fibronectin is likely to play a role in branching morphogenesis and is localized to areas of airway bifurcation (Roman \& McDonald, 1992).

\section{Cell-cell and cell-extracellular matrix receptors}

Integrins are cell-surface glycoproteins which act as matrix receptors and interact 
intracellularly with cytoskeleton proteins. The $\beta 1$ subfamily includes receptors for laminin, fibronectin and collagen (Albelda \& Buck, 1990). The distribution of two members of this $\beta 1$ subfamily in mouse lung have specific localizations during mouse lung development, with one member of this family, VLA5, localized to smooth muscle in developing bronchioles and another, VLA3, to the apical and lateral surfaces of epithelial cells, suggesting a function in cell-cell adhesion (Roman \& McDonald, 1992). Cadherins are cell-cell adhesion glycoproteins with sub-classes E-, P- and N-cadherins. Expression of E-cadherin is confined to epithelial cells and P-cadherin to epithelial and non-epithelial cells. In vitro lung development is disrupted and there is abnormal morphogenesis in the presence of antibodies to E- and P-cadherins, suggesting a role for cadherins in cell-cell interactions in lung maturation (for example Hiria et al. 1989). Syndecans are a family of cell-surface glycoproteins whose structure and cellular distribution changes with mouse lung development, with a reduction in molecular size and down-regulation of expression in terminally differentiating alveolar epithelium (Brauker et al. 1991).

\section{GROWTH FACTORS AND LUNG DEVELOPMENT}

Growth factors contribute not only to the control of mitosis in the developing lung but some act as mediators of differentiation. A growth factor is produced locally within a tissue and may act on the cell in which it was produced (autocrine) or on neighbouring cells (paracrine). The synthesis of a growth factor may be regulated by other growth factors or hormones and in turn the effect of a growth factor on a cell may depend on interactions with yet other growth factors and hormones.

\section{Fibroblast-pneumocyte factor (FPF)}

FPF stimulates surfactant production and SP-A expression in type II pneumatocytes (Smith, 1979). FPF production is positively regulated by corticosteroids and negatively by transforming growth factor (TGF)- $\beta$. Dihydrotestosterone interferes with the progression of lung development by delaying the appearance of FPF in developing lung.

\section{Prostaglandins}

Lung primordium is a self-differentiating system in vitro. In organ culture from human fetuses, as early as 12 weeks gestation, the epithelium differentiates into type II pneumatocytes containing lamellar bodies of surfactant. In addition, terminal airspaces dilate and the epithelial lining cells flatten to type I pneumatocytes. These morphological changes, together with the evidence that surfactant is synthesized, confirm that accelerated development has occurred, with the morphological appearance of a 26-week gestation lung (Cossar et al. 1993). These changes occur in sera-free media in the absence of exogenous hormones or growth factors, suggesting the presence of endogenous regulatory factors. Prostaglandins are produced in substantial amounts by human fetal lung in culture (Hume et al. 1991), possibly as a result of oxidative and mechanical stresses (Hume et al. 1993). Indomethacin inhibits endogenous prostaglandin production, the process of accelerated self-development and the spontaneous induction of SP-A gene expression. Addition of exogenous prostaglandin $E_{2}$ reverses the indomethacin 
inhibition on morphological development and SP-A expression (Accaregui et al. 1990; Ballard et al. 1991; Hume et al. 1991).

\section{Epidermal growth factor}

EGF accelerates fetal lung budding and growth (Yasui $e$ t al. 1993). EGF also accelerates maturation of type II pneumatocytes, with the earlier appearance of phospholipid surfactant as well as increases in SP-A mRNA and protein, with lung maturation retarded in the presence of anti-EGF antibodies. Androgens, both in vivo and in vitro, inhibit lung maturation, and it is proposed that part of their mechanism of action is to delay the appearance of EGF receptors in fetal lung (Klein \& Nielsen, 1993).

\section{Transforming growth factor- $\alpha$}

TGF- $\alpha$, a member of the EGF family, is a potent mitogen for several cell lines and acts via the receptor. In developing mid-gestation human fetal lung, TGF- $\alpha$ is found in all epithelial cells, but particularly in bronchiolar cells, suggesting a role in distal airway formation. Consistent with this proposal, ontogenic studies in fetal rat lung have shown that highest levels of TGF- $\alpha$ protein and mRNA are found in canilicular lung at a time of distal airway remodelling (for example Strandjord et al. 1993).

\section{Bombesin}

Fetal pulmonary neuroendocrine cells contain substantial amounts of bombesin-like peptides. Bombesin increases growth and maturation of mouse lung both in vivo and in vitro with increased production of surfactant and SP-A protein, effects antagonized by anti-bombesin receptor antibodies. Bombesin-like peptides are hydrolysed by a specific neutral endopeptidase expressed in bronchial epithelium and it is suggested that expression of this protease in turn controls the bioavailability of bombesin-like peptides (King et al. 1993). In studies using monoclonal anti-bombesin antibodies to inhibit bombesin-like peptide action, there is an increase in the number of lung EGF receptors, suggesting an inter-relationship exists between these growth factors which have similar effects on developing lung (Sunday et al. 1993).

\section{Transforming growth factor- $\beta$}

TGF- $\beta$ inhibits the production of SP-A from type II pneumatocytes in human fetal lung. The localization of epithelial and mesenchymal TGF- $\beta$ changes with development and parallels alterations in matrix proteins and glycosaminoglycans, suggesting that TGF- $\beta$ may have a role in the control of branching morphogenesis (Whitsett et al. 1987b; Heine et al. 1990). Spatial and temporal patterns of expression of the isoforms of TGF- $\beta$ (TGF- $\beta 1,-\beta 2$ and $-\beta 3$ ) in human embryonic lung are distinct and may play different roles during lung morphogenesis (Gatherer, 1990). TGF- $\beta 1$ has a role in regulating lung elastin production by increasing levels of soluble elastin mRNA, with developing lung most responsive to TGF- $\beta 1$ (McGowan, 1992).

\section{Insulin-like growth factors (IGF)}

IGF are developmentally regulated, with IGF-II expression occurring primarily during 
fetal and IGF-I during postnatal development (Davenport et al. 1987). IGF-I and IGF-II bind to a large family of IGF-binding proteins (IGFBP) which may regulate the activity of IGF (Wood et al. 1992). Studies of IGFBP 2 expression show that this predominates during fetal development and as IGF-II protein co-localizes with IGFBP 2 mRNA, suggest that IGF-II is synthesized by the mesenchyme but acts on epithelial cells during lung development (Klempt et al. 1992). Changes in pulmonary cell division and IGF-II gene expression have been observed following changes in fetal lung liquid (Hooper et al. 1993).

\section{Fibroblast growth factors (FGF)}

FGF, acidic (aFGF) and basic (bFGF) have potential roles in morphogenic control. The cellular responses of FGF are mediated by a family of specific receptors for tyrosine kinases (Gospodarowicz, 1990) and two FGF receptors (FGFR), FGFR1 and FGFR2, show developmental and spatial differences (Peters et al. 1992), but the functional significance of this is not known. It is possible that bFGF is involved in the control of lung proliferation during development as adult pulmonary type II cells respond with proliferation (Leslie et al. 1990).

\section{HORMONAL REGULATION AND LUNG DEVELOPMENT}

Hormonal control of lung maturation allows synchronization with key developmental processes in other fetal organs. The effects of a hormone on a target cell may be modulated by interactions with other hormones and growth factors.

\section{Glucocorticoids}

Since Liggins (1969) showed that glucocorticoid administration to fetal lambs in utero reduced the incidence of respiratory distress, many studies have shown that glucocorticoids accelerate the morphological and biochemical maturation of the lung and this effect is further augmented by agents that increase intracellular cyclic AMP (Mendelson \& Boggaram, 1991). Nucleotide sequences corresponding to glucocorticoid-responsive elements have been identified from the gene sequences of SP-A, SP-B and SP-C (for example Mendelson et al. 1991). The effects of glucocorticoids on fetal lung are time and species specific (Odom et al. 1988). In contrast to the complex effects on SP-A gene expression, glucocorticoids stimulate increases in the levels of SP-B and SP-C mRNA in a dose-dependent manner (Mendelson \& Boggaram, 1991).

\section{$\beta$-Adrenergic receptor agonists}

Catecholamines bind to $\beta$-adrenergic receptors on type II pneumatocytes and raise intracellular cAMP levels. $\beta$-Adrenergic-receptor numbers on type II pneumatocytes increase with gestational age. In addition, it has been suggested that the $\beta$-adrenergic receptor numbers can be further increased by administration of corticosteroids, although more recent studies in human fetal lung have shown down-regulation of receptors (for example Odom et al. 1987). Factors which increase intracellular cAMP levels in fetal lung cells accelerate the morphological maturation of lung and increase the synthesis of 
surfactant, including the SP-A mRNA and protein components (Whitsett et al. 1987a). In contrast to the marked stimulatory effect of cAMP on SP-A, only modest increases are seen in SP-B and SP-C mRNA levels in human lung but without a concomitant rise in the corresponding protein levels. Consensus cAMP-dependent responsive elements have been identified on SP-A, -B and -C genes (Gross, 1990; Mendelson \& Boggaram, 1991).

\section{Thyroid hormones}

Triiodothyronine $\left(\mathrm{T}_{3}\right)$ and thyroxine $\left(\mathrm{T}_{4}\right)$ enhance fetal lung surfactant phospholipid production, particularly DPPC, both in vivo and in vitro, but do not appear to increase surfactant proteins SP-A, SP-B or SP-C (for example Lilly et al. 1989). Since neither thyroid hormones nor thyroid-stimulating hormone crosses the human placenta, thyrotropin-releasing hormone (TRH) has been used as a means of elevating fetal $\mathrm{T}_{3}$. TRH increases DPPC in rabbits and lambs and when combined with glucocorticoids, but not alone, increases lung distensibility. In human and animal in vitro and in vivo studies, glucocorticoids and $\mathrm{T}_{3}$ synergistically increase DPPC synthesis but $\mathrm{T}_{3}$ does not increase the glucocorticoid induction of surfactant protein synthesis and antagonism exists for other key developmental changes such as the glucocorticoid stimulation of glycogenolysis and fatty acid synthase (EC 2.3.1.85) activity in fetal lung (Nichols et al. 1990).

\section{Prolactin}

The balance of evidence from human and animal studies suggests a role for prolactin in lung development. In human lung cultures, prolactin enhances glucocorticoid stimulation of DPPC synthesis and surfactant secretion (Mendelson et al. 1981). Fetal plasma prolactin levels increase before the change in lecithin:sphingomyelin (L:S) and there is a negative correlation between cord plasma prolactin levels and respiratory distress syndrome (Gluckman et al. 1978). In lambs the combination of glucocorticoids, $\mathrm{T}_{3}$ and prolactin increases lung distensibility and this may be an important maturation effect (Schellenberg et al. 1988).

\section{Insulin}

Infants of diabetic mothers have an increased incidence of respiratory distress syndrome often with normal $\mathrm{L}: \mathrm{S}$ values in amniotic fluid but with reduced or absent PG. The balance of evidence suggests insulin has no direct effect on PG synthesis, but instead is inhibitory to the synthesis of surfactant protein SP-A in human fetal lung (Snyder et al. 1988). In human fetal lung in organ culture, insulin reduces SP-A synthesis in a dose-dependent manner and when combined with glucocorticoid has a synergistic effect to further reduce SP-A levels. Phospholipid surfactant synthesis under these conditions is increased and it is suggested that the effect of fetal hyperinsulinaemia in diabetic pregnancies is to produce a surfactant with reduced SP-A content. Insulin at higher concentrations inhibits the production of SP-B but has no effect on SP-C (Dekowski \& Snyder, 1992). In addition to hyperinsulinaemia, infants of diabetic mothers may have raised levels of $\alpha$-aminobutyric acid, which in rat lung in vitro inhibits the formation of SP-A but not SP-B (Nichols et al. 1990).

Androgens, oestrogens and fetal sex

Clinical observations suggest that male lung development lags behind females by 1-2 
weeks, with a corresponding increase in respiratory distress syndrome. Androgens delay human lung maturation in vitro and the appearance of phospholipid surfactant. Dihydrotestosterone inhibits the dexamethasone-stimulated formation of surfactant phospholipid. A number of mechanisms of action of dihydrotestosterone have been proposed, including inhibition of FPF synthesis (see growth factors) and delaying the appearance of epithelial EGF receptors during fetal lung development (Torday, 1990; Klein \& Nielsen, 1993). Oestrogens significantly increase phospholipid synthesis when administered to fetal rabbits and also increase surfactant proteins SP-A and SP-B but decrease amounts of SP-C, with inconsistent effects in other species and preparations (for example Connelly et al. 1991).

\section{FETAL LUNG SECRETION}

Fetal lung secretion involves a mechanism based on secondary active $\mathrm{Cl}^{-}$secretion, and airway fluid distension in utero has a role in the control of fetal lung growth (Olver, 1994). The developing lung is compressed in diaphragmatic hernia and oligohydramnios syndromes, and this reduction in space for lung volume expansion results in lung hypoplasia (Wigglesworth \& Desai, 1981). Lung compression markedly reduces lung cell proliferation and, in parallel, reduces the DNA content per unit dry mass, with a reduction in acini formed in early gestation or, if the compression is later, the number of alveoli present (Moessinger et al. 1986). Increasing lung volume expansion, as occurs in laryngeal artesia or experimentally in fetal tracheal ligation, results in lung hyperplasia and conversely lung liquid drainage results in reduced growth (Hooper et al. 1993). The effects of changes in lung volume on fetal lung maturation are less pronounced and may only become obvious if the mitotic activity of the fetal lung has been severely compromised during the canilicular phase. There appears to be no correlation between fetal breathing movements and lung growth. In addition, lung fluid secretion rate is not influenced by fetal breathing movements and the volume changes between periods of apnoea and breathing are so small that it is unlikely that fetal breathing influences lung growth through changes in lung fluid secretion or volume (Harding et al. 1986). The transition from intrauterine placental to pulmonary gas exchange requires a switch from lung secretion to absorption of lung liquid. Adrenaline and, to a lesser extent, vasopressin activate cAMP-dependent pathways that increase $\mathrm{Na}^{+}$absorption in the apical membranes of type II pneumatocytes (for review, see Olver, 1994).

\section{CONCLUSION}

The developmental regulation of lung ontogeny is a complex interaction of multiple and interacting levels of molecular control. The critical role of nutrient supply to this developmental process has only begun to be appreciated. The further delineation of the nutritional contribution to lung maturation is likely to be of fundamental importance not only to the well-being of the fetus and infant but beyond into adulthood.

The work done in Dundee was supported by the Wellcome Trust, Action Research, Wellbeing-RCOG, Sir Halley Stewart Trust and Tenovus (Scotland). 


\section{REFERENCES}

Accaregui, M. J., Snyder, J. M., Mitchell, M. D. \& Mendelson, C. R. (1990). Prostaglandins regulate surfactant protein A (SP-A) gene expression in human fetal lung in vitro. Endocrinology 127, 1105-1113.

Albelda, S. M. \& Buck, C. A. (1990). Integrins and other cell adhesion molecules. FASEB Journal 4, 2868-2880.

Ballard, P. L., Gonzales, L. W., Williams, M. C., Roberts, J. M. \& Jacoobs, M. M. (1991). Differentiation of type II cells during explant culture of human fetal lung is accelerated by endogenous prostanoids and adenosine 3,5-monophosphate. Endocrinology 128, 2916-2924.

Barker, D. J. (1992). The effect of nutrition of the fetus and neonate on cardiovascular disease in adult life. Proceedings of the Nutrition Society 51, 135-144.

Beech, D. J., Sibbons, P. D., Howard, C. V. \& van Velzen, D. (1995). Absolute terminal bronchiolar duct number in lungs and SIDS and IUGR. Journal of Developmental Physiology 20, 199-201.

Brauker, J. H., Trautman, M. S. \& Bernfield, M. (1991). Syndecan, a cell surface proteoglycan, exhibits a molecular polymorphism during lung development. Developmental Biology 147, 285-292.

Connelly, I. H., Hammond, G. L., Harding, P. G. \& Possmayer, F. (1991). Levels of surfactant-associated protein messenger ribonucleic acids in rabbit lung during perinatal development and after hormonal treatment. Endocrinology 129, 2583-2591.

Cossar, D., Bell, J., Lang, M. \& Hume, R. (1993). Development of human fetal lung in organ culture compared with in utero ontogeny. In Vitro Cellular and Developmental Biology 29A, 319-324.

Davenport, J. L., D'Ercole, A. J., Azizkhan, J. C. \& Lund, P. K. (1987). Somatomedin-CC/insulin-like growth factor I (Sm-C/IGF-I) and insulin-like growth factor II (IGF-II) mRNAs during lung development in the rat. Experimental Lung Research 14, 607-618.

Dekowski, S. A. \& Snyder, J. M. (1992). Insulin regulation of messenger ribonucleic acid for the surfactant-associated proteins in human fetal lung in vitro. Endocrinology 131, 669-676.

Endo, H. \& Oka, T. (1991). An immunohistochemical study of bronchial cells producing surfactant protein A in the developing human fetal lung. Early Human Development 25, 149-156.

Gatherer, D., Dijke, P. T., Baird, D. T. \& Akhurst, R. J. (1990). Expression of TGF- $\beta$ isoforms during first trimester human embryogenesis. Development 110, 445-460.

Gaunt, S. J., Krumlauf, R. \& Duboule, D. (1989). Mouse homeo-genes within a subfamily, Hox-1.4, -2.6 and -5.1 , display similar anteroposterior domains of expression in the embryo, but show stage- and tissuedependent differences in their regulation. Development 107, 131-141.

Gavin, B. J., McMahan, J. A. \& McMahon, A. P. (1990). Expression of multiple novel Wnt-1/int-1-related genes during fetal and adult mouse development. Genes and Development 4, 2319-2332.

Gluckman, P. D., Ballard, P. I., Kaplan, S. L., Liggins, G. C. \& Grumbach, M. M. (1978). Prolactin in umbilical cord blood and the respiratory distress syndrome. Journal of Pediatrics 93, 1011-1014.

Gospodarowicz, D. (1990). Fibroblast growth factor and its involvement in developmental processes. Current Topics in Developmental Biology 24, 57-93.

Graham, A., Papolopulu, N. \& Krumlauf, R. (1989). The murine and Drosophila homeobox gene complexes have common features of organization and expression. Cell 57, 367-378.

Gross, I. (1990). Regulation of fetal lung maturation. American Journal of Physiology 259, L337-L344.

Hansbrough, J. R., Fine, S. M. \& Gordon, J. I. (1993). A transgenic mouse model for studying the lineage relationships and differentiation program of type II pneumocytes at various stages of lung development. Journal of Biological Chemistry 268, 9762-9770.

Harding, J. E. (1996). Consequences of experimental manipulation of perinatal nutrition. Journal of Developmental Physiology (In the Press).

Harding, R., Bocking, A. D. \& Sigger, J. N. (1986). Upper airway resistances in fetal sheep: the influence of breathing activity. Journal of Applied Physiology 60, 160-165.

Heine, U. I., Munoz, E. F., Flanders, K. C., Roberts, A. B. \& Sporn, M. B. (1990). Colocalisation of TGF-beta 1 and collagen I and III, fibronectin and glycosaminoglycans during lung branching morphogenesis. Development 109, 29-36.

Hirai, Y., Nose, A., Kobayashi, S. \& Takeichi, M. (1989). Expression and role of E- and P-cadherin adhesion molecules in embryonic histogenesis. Development 105, 263-270.

Hirning, U., Schmid, P., Schulz, W. A., Rettenberger, G. \& Hameister, H. (1991). A comparative analysis of $\mathrm{N}$-myc and c-myc expression and cellular proliferation in mouse organogenesis. Mechanisms of Development 33, 119-126.

Hislop, A. \& Reid, L. (1974). Development of the acinus in the human lung. Thorax 29, 90-94. 
Hislop, A. A., Wigglesworth, J. S. \& Desai, R. (1986). Alveolar development in the human fetus and infant. Early Human Development 13, 1-11.

Hooper, S. B., Han, V. K. M. \& Harding, R. (1993). Changes in lung expansion after pulmonary DNA synthesis and IGF-II gene expression in fetal sheep. American Journal of Physiology 265, L403-L409.

Hume, R., Bell, J., Gourlay, M., Giles, M., Hallas, A., Cossar, D. \& Kelly, R. (1993). Prostaglandin production and metabolism in self-differentiating human fetal lung organ culture. Experimental Lung Research 19, 361-376.

Hume, R., Cossar, D., Kelly, R., Giles, M., Hallas, A., Gourlay, M. \& Bell, J. (1992). Prostaglandins PGE 2 and $\mathrm{PGF}_{2 \alpha}$ in human fetal lung: immunohistochemistry and rejease from organ culture. Experimental Lung Research 18, 259-273.

Hume, R., Kelly, R., Cossar, D., Giles, M., Hallas, A., Gourlay, M. \& Bell, J. (1991). Self-differentiation of human fetal lung in organ culture: the role of prostaglandins $\mathrm{PGE}_{2}$ and $\mathrm{PGF}_{2 \alpha}$. Experimental Cell Research 194, 111-117.

King, K. A., Hua, J., Torday, J. S., Drazen, J. M., Graham, S. A., Shipp, M. A. \& Sunday, M. E. (1993). CD10/neutral endopeptidase 24.11 regulates fetal lung growth and maturation in utero by potentiating endogenous bombesin-like peptides. Journal of Clinical Investigation 91, 1969-1973.

Klein, J. M. \& Nielsen, H. C. (1993). Androgen regulation of epidermal growth factor receptor binding activity during fetal rabbit lung development. Journal of Clinical Investigation 91, 425-431.

Klempt, M., Hutchins, A.-M., Gluckman, P. D. \& Skinner, S. J. M. (1992). IGF binding protein-2 gene expression and the location of IGF-I and IGF-II in fetal rat lung. Development 115, 765-772.

Leslie, C. C., McCormick-Shannon, K. K. \& Mason, R. J. (1990). Heparin binding growth factors stimulate DNA synthesis in rat alveolar type II cells. American Journal of Respiratory Cell and Molecular Biology 2 , 99-106.

Levay-Young, B. K. \& Navre, M. (1992). Growth and development regulation of wnt-2 (irp) gene in mesenchymal cells of fetal lung. American Journal of Physiology 262, L672-L683.

Liggins, G. C. (1969). Premature delivery of foetal lambs infused with glucocorticoids. Endocrinology 45 , $515-523$.

Liley, H. G., White, R., Warr, R., Benson, B. J. \& Ballard, P. L. (1989). Regulation of messenger RNAs for the hydrophobic surfactant proteins in human lung. Journal of Clinical Investigation 83, 1191-1197.

McGowan, S. E. (1992). Influences of endogenous and exogenous TGF-beta on elastin in rat lung fibroblasts and aortic smooth muscle cells. American Journal of Physiology 263, L257-L263.

Mendelson, C. R. \& Boggaram, V. (1991). Hormonal control of the surfactant system in fetal lung. Annual Review of Physiology 53, 415-440.

Mendelson, C. R., Johnson, J. M., MacDonald, P. C. \& Snyder, J. M. (1991). Multihormonal regulation of surfactant synthesis by human fetal lung in vitro. Journal of Clinical Endocrinology and Metabolism 53, 307-317.

Moens, C. B., Auerbach, A. B., Conlon, R. A., Joyner, A. L. \& Rossant, J. (1992). A targeted mutation reveals a role for $\mathrm{N}$-myc in branching morphogenesis in the embryonic mouse lung. Genes and Development 6, 691-704.

Moessinger, A. C., Collins, M. H. \& Blanc, W. A. (1986). Oligohydramnios-induced lung hypoplasia: the influence of timing and duration in gestation. Pediatric Research 20, 951-954.

Nichols, K. V., Floros, J., Dynia, D. W., Veletza, S. V., Wilson, C. M. \& Gross, I. (1990). Regulation of surfactant protein A mRNA by hormones and butyrate in cultured fetal rat lung. American Journal of Physiology 259, L488-L495.

Odom, M. J., Snyder, J. M., Boggaram, V. \& Mendelson, C. R. (1988). Glucocorticoid regulation of the major surfactant-associated protein (SP-A) and its RNA and of morphological development of human fetal lung in vitro. Endocrinology 123, 1712-1720.

Odom, M. J., Snyder, J. M. \& Mendelson, C. R. (1987). Adenosine 3',5'-monophosphate analogs and $\beta$-adrenergic agonists induce the synthesis of the major apoprotein in human fetal lung in vitro. Endocrinology 122, 1155-1163.

Olver, R. E. (1994). Fluid secretion and absorption in the fetus. In Fluid and Solute Transport in the Airspaces of the Lungs. Lung Biology in Health and Disease, vol. 70, pp. 281-302 [R. M. Effros and H. K. Chang, editors]. New York: Marcel Dekker Inc.

O'Rahilly, R. (1988). The early prenatal development of the human respiratory system. In Pulmonary Development from Intrauterine to Extrauterine Life. Lung Biology in Health and Disease, vol. 27, pp. 3-18 [G. H. Nelson, editor]. New York: Marcel Dekker Inc. 
Peters, K. G., Werner, S., Chen, G. \& Williams, L. T. (1992). Two FGF receptor genes are differentially expressed in epithelial and mesenchymal tissues during limb formation and organogenesis in the mouse. Development 114, 233-243.

Rees, S., Ng, J., Dickson, K., Nicholas, T. \& Harding, R. (1991). Growth retardation and the development of the respiratory system in fetal sheep. Early Human Development 26, 13-27.

Roman, J. \& McDonald, J. A. (1992). Expression of fibronectin, the integrin $\alpha 5$, and $\alpha$-smooth muscle actin in heart and lung development. American Journal of Respiratory Cell and Molecular Biology 6, 472-480.

Ryan, R. M., Morris, R. E., Rice, W. R., Ciraola, G. \& Whitsett, J. A. (1989). Binding and uptake of pulmonary surfactant protein (SP-A) by pulmonary type II epithelial cells. Journal of Histochemistry and Cytochemistry 37, 429-440.

Sawai, S., Shimono, A., Wakamatsu, Y., Palmes, C., Hanaoka, K. \& Konoloh, H. (1993). Defects of embryonic organogenesis resulting from targeted disruption of the $\mathrm{N}$-myc gene in the mouse. Development 117, 1445-1455.

Schellenberg, J., Liggins, G. C., Manzia, M., Kitterman, J. A. \& Lee, C. C. H. (1988). Synergistic hormonal effects on lung maturation in fetal sheep. Journal of Applied Physiology 65, 94-100.

Schuger, L., Skubitz, A. P. N., O'Shea, K. S., Chang, J. F. \& Varani, J. (1991). Identification of laminin domains involved in branching morphogenesis: Effects of anti-laminin monoclonal antibodies on mouse embryonic lung development. Developmental Biology 146, 531-541.

Smith, B. T. (1979). Lung maturation in the fetal rat: acceleration by injection of fibroblast pneumocyte factor. Science 204, 1094-1095.

Snyder, J. M., Longmuir, K. J., Johnson, J. M. \& Mendelson, C. R. (1988). Hormonal regulation of the synthesis of lamellar body phosphatidylglycerol and phosphatidylinositol in fetal lung tissue. Endocrinology 112, 1012-1018.

Strandjord, T. P., Clark, J. G., Hodson, W. A., Schmidt, R. A. \& Madtes, D. K. (1993). Expression of transforming growth factor-alpha in mid-gestation human fetal lung. American Journal of Respiratory Cell and Molecular Biology 8, 266-272.

Sunday, M. E. H., Hua, J., Reyes, B., Masui, H. \& Torday, J. S. (1993). Anti-bombesin monoclonal antibodies modulate fetal mouse lung growth and maturation in utero and in organ cultures. Anatomical Record 236, 25-34.

Symonds, M. E., Bird, J. A., Clarke, L., Gate, J. J. \& Lomax, M. A. (1996). Nutrition, temperature and homeostasis during perinatal development. Journal of Developmental Physiology (In the Press).

Torday, J. S. (1990). Androgens delay human fetal lung maturation in vitro. Endocrinology 126, 3240-3244.

Torday, J. S., Nielsen, H. C., Fencl, M. \& Avery, M. E. (1981). Sex differences in fetal lung maturation. American Review of Respiratory Disease 123, 205-208.

Vartio, T., Laitinen, L., Narvanen, O., Cutolo, M. \& Thornell, L. (1987). Differential expression of the ED sequence-containing form of cellular fibronectin in embryonic and adult human tissues. Journal of Cell Science 88, 419-430.

Whitsett, J. A., Pilot, T., Clarke, J. C., Sawtell, N. \& Glasser, S. W. (1987a). Induction of surfactant protein in fetal lung: Effects of cAMP and dexamethasone on SAP-35 RNA and synthesis. Journal of Biological Chemistry 262, 5256-5261.

Whitsett, J. A., Weaver, T. A., Lieberman, M. A., Clark, J. C. \& Daugherty, C. (1987b). Differential effects of epidermal growth factor and transforming growth factor $\beta$ on synthesis of $\mathrm{Mr}=35,000$ surfactantassociated protein in fetal lung. Journal of Biological Chemistry 262, 7908-7913.

Wigglesworth, J. S. \& Desai, R. (1981). Use of DNA estimation for growth assessment in normal and hypoplastic fetal lungs. Archives of Disease in Childhood 56, 601-605.

Wohlford-Lenane, C. L., Durham, P. L. \& Snyder, J. M. (1992). Localization of surfactant-associated protein $\mathrm{C}$ (SP-C) mRNA in fetal rabbit lung tissue by in situ hybridization. American Journal of Respiratory Cell and Molecular Biology 6, 225-234.

Wolgemuth, D. J., Behringer, R. R., Mostoller, M. P., Brinster, R. L. \& Palmiter, R. D. (1989). Transgenic mice over-expressing the mouse homeobox containing gene Hox-1.4 exhibit abnormal gut development. Nature 337, 464-467.

Wood, T. L., Streck, R. D. \& Pintar, J. E. (1992). Expression of the IGFBP-2 gene in post-implantation rat embryos. Development 114, 59-66.

Wu, T. C., Wan, Y. J., Chung, A. E. \& Damajonov, I. (1983). Immunohistochemical localization of entactin and laminin in mouse embryos and fetuses. Developmental Biology 100, 496-505.

Yasui, S., Nagai, A., Oohira, A., Iwashita, M. \& Konno, K. (1993). Effects of anti-mouse EGF antiserum on prenatal lung development in fetal mice. Pediatric Pulmonology 15, 251-256. 